\title{
Evaluating efficiency levels comparatively: data envelopment analysis application for turkish textile and apparel industry
}

\author{
Canan Saricam, Nazan Erdumlu \\ Istanbul Technical University, Istanbul Technical University (Turkey) \\ canansaricam@gmail.com,nazanokun@gmail.com
}

Received: September 2012

Accepted: November 2012

\section{Abstract:}

Purpose: The purpose of this study is to show the usage of DEA in efficiency measurement.

Design/methodology/approach: The efficiencies of textile and apparel companies were analyzed by input-oriented DEA model under variable return to scale assumption. The textile and apparel companies quoted in Istanbul Stock Exchange for the period 2003 and 2008 were evaluated in terms of efficiency level providing a framework for the calculation of input excesses and output shortages.

Findings: The analysis revealed that the average efficiency scores of the apparel industry was higher than the textile industry and two industries together. The companies in the apparel industry should overcome the lack of insufficient level of exports whereas the textile industry needs to increase gross value added in order to be more efficient.

Research limitations/implications: Because of missing data, four companies from textile industry and one company from apparel industry were ignored although they took place in the records of Istanbul Stock Exchange.

Practical implications: This study provided a framework for DEA application in determination and comparison of efficiency performance in an industry level.

Originality/value: Selecting the groups compared as textile industry, apparel industry and the two industries in general allowed discussing the comparative efficiencies of two industries eliminating the industry specific pitfalls.

Keywords: data envelopment analysis, textile industry, apparel industry, efficiency measurement 


\section{Introduction}

Textile and apparel industry, which is labor intensive and requires low level of investment, has great significance for countries especially in their early stages of development. Although, the share of the textile and apparel industry among the other industries decreases when economies of countries get better, developed countries continue to compete in this arena usually with higher value added garments and products. Flexibility in meeting the demands of the customers while minimizing the input and maximizing the output is a challenging issue (Lin, Kincade \& Warfield, 1994). Flexibility can be developed via specialization and the computer and worker together can produce different products and change operations when needed (Zhang \& Hathcote, 2008). Cost minimization at the same time is difficult however. The wage differences between countries enable global shifts to occur in apparel production due to the differences between countries in relative abundance of labor and capital (Loker, 2002). Thus, a challenging situation is raised by low cost producing countries especially in the periods of downturn. Within this respect, the countries acting in textile and apparel business should make introspection into their industry performance; increase their outputs but decrease their resource usage. The countries which have the experience, potential and huge investments in these fields, are strongly suggested to improve themselves in terms of producing in more productive and efficient manner if they aim to maintain high level of competitiveness.

The efficiency based performance evaluations are required to make a valid comparison among the industries as well as within the industry. This necessity can clearly be seen with an example of Turkey. In Turkey, 2 to 3 million people are employed in textile and apparel industry, whereas 2 million people are employed in these fields in European countries. Despite that large amount of employment, the total revenue of Turkish textile and apparel industry is between 25 to 45 billion dollars, whereas that value reaches about 250 billion dollars for European countries (BTSO). The profitability range in textile industry lies between 5 and 10\% depending on the product market and customer whereas it is between 10 and $20 \%$ in the developed countries (Ayvaci, 2011). Within this regard, the profitability and efficiency should be measured in order to manage well.

There are many efficiency measurement techniques which cover simple ration analysis, sophisticated mathematical and statistical modeling, but regression analysis and data envelopment analysis come forward (Cubbin \& Tzanidakis, 1998). While statistical approaches focus on averages of the parameters, DEA considers individual observation (Tongzon, 2001). Data Envelopment Analysis (DEA) is a nonparametric efficiency measurement method that uses mathematical programming and has the ability to evaluate the performances of a set of entities called Decision Making Units (DMUs) which convert multiple inputs into multiple outputs, and to identify both inefficient DMUs and the magnitude of the efficiency (Sherman \& Zhu, 2006; Ray, 2004). 
The superiority of DEA method over the parametric models is that it does not require the specification of any functional relationship between inputs and outputs (Chandra, Cooper, Shanling, \& Rahman, 1998) and a reference is not determined according to whom the efficiency is measured. DEA gathers all the partial efficiency measures together in order to carry out the overall efficiency measure (Tongzon, 2001). DEA ranks the DMUs into two as efficient and inefficient DMUs (Adler, Friedman \& Stern, 2002). Besides, it can consider more than one output whereas it does not require the determination of the priority issues among the inputs and outputs (Tongzon, 2001). Moreover, DEA in efficiency measurement eliminates the problems that can lead to wrong results of the efficiency measurement in which only the separate production factors are isolated (Goncharuk, 2007). Cubbin and Tzanidakis (1998) reveal that DEA is good at identifying possible reasons for poor performances by providing a checklist for the management staff.

Considering the advantages of DEA method on efficiency measurement, a framework was established to show the application of DEA in efficiency evaluation and comparison, which provides a case for the industries having the same requirement of performance assessment. To this aim, DEA method was applied in Turkish textile and apparel industry for determining the performance of the companies which are quoted in Istanbul Stock Exchange. The overall performance of the textile and apparel industries were established and compared with each other to discover the problematic fields with an additional analysis of input excesses and output shortfalls as explanations of low performances.

\section{Literature Review}

The literature review is composed of three parts. In the first part, the definition and features of DEA procedure is given. In the second part, the use of DEA method in different field of applications is presented. In the third part, specific examples regarding textile and apparel industry were given with the introduction of the parameters used as inputs and outputs in the establishment of DEA.

The first DEA model was introduced by Charnes, Cooper and Rhodes, which is called CCR, in 1978. The model is used to calculate the relative efficiency of the DMUs based on constant return to scale assumption. In 1984, BCC model was developed by Banker, Charnes and Cooper, which is referred to as the VRS (Variable Returns to scale) model. Two alternative approaches are available in both models as input oriented and output oriented. In the inputoriented models, inputs are minimized and the outputs are kept at their current levels. In the output-oriented models, outputs are maximized while using no more than the observed amount of any input (Duzakin \& Duzakin, 2007; Charnes, Cooper \& Rhodes, 1978; Banker, Charnes \& Cooper, 1984). 
Based on the mathematical programming theory, DEA is an efficiency evaluation method which creates an optimization for the individual observation by evaluating a discrete piece-wise frontier. Efficiency refers to the quotient from the division of the sum of all outputs by the sum of all inputs (Goncharuk, 2007). In data envelopment analysis, the frontier is found out by the set of Pareto efficient decision management units (Tongzon, 2001). The factors in DEA calculations are not subjected to rigid importance weights whereas in conventional techniques, the inputs are given weight in terms of creation only one output. DEA allows finding out the reference set which can act as benchmarks instead of finding one most efficient reference. DEA method is based on the fact that the efficiency of a DMU is determined by its ability to transform the inputs into desired outputs (Tongzon, 2001).

According to the study of Emrouznejad, Parker and Tavares (2008), DEA became in the concern of researchers over 30 years whereas the number of paper related with DEA increased to approximately 360 per year within the time period of 2004-2006 focusing specifically on the fields of banking, education (including higher education), health care, and hospital efficiency. The studies covered many applications established at a company or industry level. Laughlin and Kean (2002) used DEA for benchmarking in strategic planning. In this study, the data was obtained and analyzed for comparing teaching and research activities in textiles and clothing programs. Chandra et al. (1998) used DEA to evaluate the performance of 29 Canadian textile companies using the Cooper and Rodes model. Goncharuk (2007) investigated the impact of political changes on industrial efficiency. Tongzon (2001) used DEA procedure to calculate the selected port efficiencies in Australia for which the output measures were taken as cargo throughput and ship working rate. Gonzalez and Trujillo (2008) applied DEA analysis in order to measure the efficiency and productivity in the port industry. Taymaz and Saatci (1997) investigated the rate and direction of technical change in three industries which were textile, cement and motor vehicles by using the technical efficiency level which was described as the ratio of its actual output level to the maximum possible output that could be produced by inputs utilized by the plant in the same period. Alvarez and Crespi (2003) determined the factors that could explain the observed differences in technical efficiency and the factors lying beneath the differences such as experience of workers, modernization of physical capital and innovation in products. Jajri and Ismail (2006) analyzed the trends of technical efficiency, technological change and total factor productivity growth in the Malaysian manufacturing sector for which the data was taken from the Industrial Manufacturing Survey of 1985 to 2000 collected by the Department of Statistics Malaysia using Data Envelopment Analysis. Worthington (2001) measured inefficiency in education using DEA which was preferred to regression analysis that lacked the allowance for the tradeoff between different educational outcomes.

The performances of the companies in the Turkish textile and apparel industry were evaluated by using DEA for several researchers so far in which the input and the output parameters were 
selected differently. By using input oriented model, Kayali (2009) measured technical efficiency, pure technical efficiency and scale efficiency of 29 textile companies among Fortune 500 companies listed in 2007 using number of employees, shareholders' equity and net assets as inputs, and net sales and net profits as outputs. The result of the analyses revealed that efficiency score of textile sector was equal to $57 \%$. The authors indicated that utilization of the resources was inefficient in the sector. Bayrak Ozcan, Anil and Emre (2003-2004) conducted efficiency measurement within 25 textile companies in Istanbul. They used employees, shareholders' equity and net assets as inputs, and turnover, profit before tax and export revenue as outputs. The results revealed that only 5 companies were efficient, and 7 of the rest had an efficiency ratio above 50\%, while 13 companies had an efficiency ratio below $50 \%$. Kayalidere and Kargin (2004) investigated the efficiency of companies in the textile and cement sectors that were listed in the Istanbul Stock Exchange in 2002. They performed two analyses. In the first analysis, they used the number of employees and total assets as inputs, and net sales and net profit as the outputs. In the second analysis, number of employees and tangible assets were considered as inputs, and net sales and net profit were considered as the outputs. According to the results, they tried to determine how much inefficient companies should improve their input-output amounts to be efficient and productive compared to the efficient companies in the sector by calculating potential improvement rates. Gozu (2003) analyzed the technical and scale efficiencies of 19 companies for 2001 and 2002 that performed in the textile, leather and apparel industry, quoted by Istanbul Stock Exchange. He used number of employees, tangible assets, paid-in capital and stocks as the inputs, and net sales and net profit as the outputs for the input-oriented DEA model. For the years 2001 and 2002, it was found that average efficiency score was 0.894 and 0,797 in terms of constant return to scale, while it was 0.940 and 0.932 in terms of variable return to scale respectively; and therefore it was concluded that the companies had generally efficient operating cycles for both years. Finally, it was suggested for the companies that were efficient in 2001, but did not have scale efficiency in 2002 to revise their scales, as well as their input and output levels. Duzakin and Duzakin (2007) used super slack based model, which allowed getting a ranking of efficient companies, in order to analyze the performances of the 500 major companies in Turkey and the performances of the industries during 2003. They used net assets and the number of employees as inputs, and profit before tax, export revenues and gross value added as the outputs. They concluded that the textile, apparel and leather industry was weak in terms of profit before taxes, and an increment of $1140.32 \%$ were needed. The industry also needed an increase of $176.79 \%$ in value added for the year 2003 . The reason for inefficiency in the textile, apparel and leather industry was stated as the insufficient seasonal profits. Moreover, Arig (2011), Altin (2010), Yalama and Sayim (2008) measured and evaluated the efficiencies of manufacturing companies, including the companies in the textile, leather and apparel industry, listed in Istanbul Stock Exchange by using financial ratios as input and output variables for different periods. However, they did not evaluate each sector individually, which 
could lead to misleading results due to the different structures of the sectors. In other words, the companies being evaluated should be comparable in terms of business segment in order to perform benchmarking.

\section{Method}

In this study, the performances of the companies in the textile, apparel and leather industry quoted by Istanbul Stock Exchange for the period 2003-2008 were analyzed by input-oriented model under variable returns to scale assumption. In the input oriented BCC (Banker, Charnes and Cooper) model used in this study, the efficiency measure for Decision Making Unit (DMUo) was calculated by solving the following mathematical programming problem composed of Equations 1-4 in Excel Solver (Zhu, 2003):

$$
\theta^{*}=\min \theta
$$

subject to

$$
\begin{gathered}
\sum_{j=1}^{n}\left(\lambda_{j} x_{i j} \leq \theta x_{i 0}\right) \quad i=1,2, \ldots \ldots, m_{j} \\
\sum_{j=1}^{n}\left(\lambda_{j} y_{r j} \geq y_{r o}\right) \quad r=1,2, \ldots \ldots, s_{j} \\
\sum_{j=1}^{n}\left(\lambda_{j}=1\right) \quad \lambda \mathrm{j} \geq 0 \quad j=1,2, \ldots \ldots, n .
\end{gathered}
$$

where DMUo represents one of the $n$ DMUs under evaluation, and xio and yro are the ith input and rth output for DMUo, respectively. $\theta *$ represents the efficiency score of DMUo.

In this study, net assets and the average number of employees were used as inputs, and gross value added, profit before tax and export revenues were used as the outputs. The input and output variables were selected by considering the fact that inputs and outputs should be independent in DEA in order to obtain reasonable results. Since the two outputs, gross value added and profit before tax could take negative values, sufficiently large positive constants were added to all the values in the output data sets including negative values. This required input oriented model under variable returns to scale assumption to be used in this study (Duzakin \& Duzakin, 2007; Cook \& Zhu, 2008). If the number of inputs is $\mathrm{m}$, and the number of outputs is $s$, at least $(m+s+1)$ DMUs is required in order to conduct DEA. Another constraint is that the number of DMUs must be at least $2 *(m+s)$. In this study, the number of inputs is 2 and the number of output is 3 . The minimum number of DMU required to conduct the analysis is $(2+3+1)=6$ and $2 *(2+3)=10$. Consequently, the number of DMUs in all three analysis included in this study fulfill this requirement (Tektufekci, 2010). 
The analysis was established for 10 companies from the apparel industry and 23 companies from the textile industry which were quoted in Istanbul Stock Exchange. One company from the apparel industry and one from the textile industry were eliminated as they were not doing export whereas four companies from textile industry and one company from apparel industry were ignored as they had missing data for the select period either because of going bankrupt or existing from the stock exchange. First, the apparel and textile industries were analyzed individually, and then a general analysis was performed for all of the 33 companies. The performances of the industries were evaluated on a yearly basis and the input excesses and shortfalls leading inefficiencies were determined.

\section{Result}

Table 1 shows the results of the efficiency analysis in the textile and apparel industry individually and two industries in general (textile and apparel together). It is seen that, the average efficiency scores of the apparel industry are higher than the textile industry and two industries in general. Besides, the standard deviations and CV values of the apparel industry are quite lower than those in the selected period.

\begin{tabular}{|c|c|c|c|c|c|}
\hline & Years & $\begin{array}{l}\text { Average } \\
\text { DEA } \\
\text { scores }\end{array}$ & $\begin{array}{l}\text { Standard } \\
\text { deviations of } \\
\text { average } \\
\text { scores }\end{array}$ & CV & $\begin{array}{c}\text { No of } \\
\text { efficient } \\
\text { companies }\end{array}$ \\
\hline \multirow{6}{*}{ 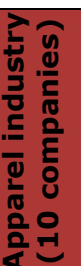 } & 2003 & 0.89 & 0.1932 & 0.2172 & 7 \\
\hline & 2004 & 0.98 & 0.0585 & 0.0596 & 9 \\
\hline & 2005 & 0.96 & 0.0864 & 0.0900 & 8 \\
\hline & 2006 & 0.88 & 0.2621 & 0.2991 & 8 \\
\hline & 2007 & 0.85 & 0.2531 & 0.2983 & 7 \\
\hline & 2008 & 0.91 & 0.1945 & 0.2128 & 8 \\
\hline
\end{tabular}

\begin{tabular}{|c|c|c|c|c|c|}
\hline \multirow{6}{*}{ 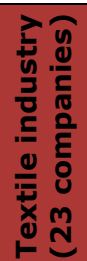 } & 2003 & 0.67 & 0.2796 & 0.4150 & 7 \\
\hline & 2004 & 0.63 & 0.3360 & 0.5315 & 8 \\
\hline & 2005 & 0.71 & 0.3038 & 0.4250 & 9 \\
\hline & 2006 & 0.59 & 0.3778 & 0.6367 & 10 \\
\hline & 2007 & 0.65 & 0.3237 & 0.4956 & 9 \\
\hline & 2008 & 0.70 & 0.3471 & 0.4956 & 11 \\
\hline
\end{tabular}

\begin{tabular}{|c|c|c|c|c|c|}
\hline \multirow{6}{*}{ 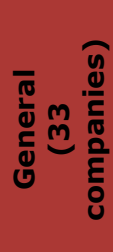 } & 2003 & 0.68 & 0.3085 & 0.4540 & 11 \\
\hline & 2004 & 0.66 & 0.3376 & 0.5151 & 12 \\
\hline & 2005 & 0.64 & 0.3351 & 0.5263 & 12 \\
\hline & 2006 & 0.59 & 0.3675 & 0.6199 & 12 \\
\hline & 2007 & 0.71 & 0.3344 & 0.4683 & 16 \\
\hline & 2008 & 0.70 & 0.3432 & 0.4869 & 16 \\
\hline
\end{tabular}

Table 1.DEA Scores, Standard Deviations and CV Values for the Selected Period

From the average DEA scores per year, the worst year for the apparel industry becomes 2007, whereas it is $\mathbf{2 0 0 6}$ for the textile industry and the two industries in general. 2006 is also the year, in which the efficiency scores of the companies differ apart from each other most considering the standard deviations. Regarding the number of efficient companies for each 
sector in concern, 2004 is the best year for the apparel industry leaving only one company behind as an inefficient one. The textile industry and the two industries in general show an improving figure by increasing the number of efficient companies in recent years.

When the results of the textile industry are compared with the scores of two industries in general, it is quite difficult to say that one of them showed a better performance than the other as their dominance on each other change with the year. For instance, in 2005, the performance of the textile industry is higher than the two industries in general while in 2003, 2004 and 2007, the industry shows worse performance than the latter one with the values differing in a range of 0.01 to 0.06 . Finally, they show the same performance in the years 2006 and 2008. On the other hand, the standard deviations of the two industries in general are higher than the score of the textile industry except the years 2006 and 2008. That means, the apparel industry is more efficient than the textile industry and the two industries in general on which the contribution of the textile industry with 23 companies lowers the performance of inefficiency.

Table 2 summarizes the overall results of the companies' successes. It is found out that 10 companies from the textile industry, 3 companies from the apparel industry and 16 companies from the 33 companies get a lower DEA score where the average efficiency values are 0.91, 0.65 and 0.66 in the apparel, textile and two industries together in 6-year-period. The apparel industry shows the highest stability with the six companies being efficient in whole period of selected years followed by the five companies from the two industries in general. Nonetheless, only two apparel companies as in the case of textile preserved their efficiencies, in the analysis of two industries in general in all years indicating poor results in terms of sustainability. It is also observed that one apparel company with the average efficiency score of 0.56 and six textile companies with the average efficiency values between 0.24 and 0.47 show the lowest performance. 8 companies out of 33 companies have the worst performance including the worst company out of the apparel industry and four low performance textile companies out of the textile industry.

\begin{tabular}{|c|c|c|c|c|}
\hline Industry & $\begin{array}{c}\text { The number } \\
\text { of companies } \\
\text { below the } \\
\text { average }\end{array}$ & $\begin{array}{c}\text { The number of } \\
\text { companies that were } \\
\text { efficient in whole } \\
\text { period of time }\end{array}$ & $\begin{array}{c}\text { The number of companies } \\
\text { that were efficient in both } \\
\text { individual and in common } \\
\text { analysis }\end{array}$ & $\begin{array}{c}\text { The number of } \\
\text { companies that never } \\
\text { became efficient during } \\
\text { the select period }\end{array}$ \\
\hline $\begin{array}{c}\text { Apparel } \\
\text { (Average efficiency 0.91) }\end{array}$ & 3 & 6 & 2 & 1 \\
\hline $\begin{array}{c}\text { Textile } \\
\text { (Average efficiency 0.65) }\end{array}$ & 10 & 2 & 2 & 6 \\
\hline $\begin{array}{c}\text { Textile and Apparel(Average } \\
\text { efficiency 0.66) }\end{array}$ & 16 & 5 & & 8 \\
\hline
\end{tabular}

Table 2. The Overall Results of Company-Base Analysis

The inefficient companies and their influence on the performance of two industries in general are depicted in detail in Figure 1 . This figure is prepared regarding the performances of the companies in the analysis of the two industries in general. To this aim, first of all, the inefficient companies that get lower scores than the average efficiency score of 33 companies 
were determined. Then, the main industries in which the companies act were determined and finally, the ratio of inefficient companies to the total companies in each industry individually was calculated and shown in Figure 1 using the percentages. For instance, in 2003, two companies from the apparel industry are found to be inefficient in the analyses of two industries in general. As there are 10 companies from the apparel industry among the 33 companies, inefficiency ratio becomes $2 / 10$ or $20 \%$.

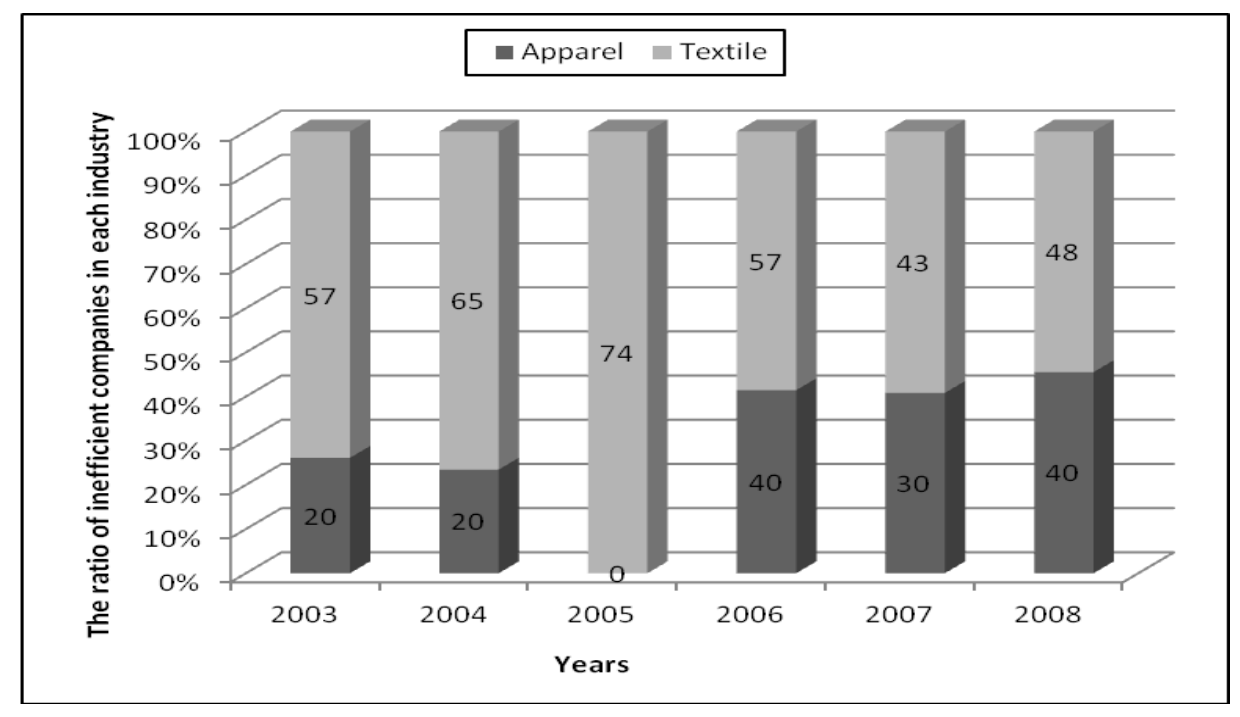

Figure 1 . The ratio of inefficient companies within each industry

When Figure 1 is analyzed considering the whole period, it depicts that the ratio of inefficient companies from the apparel industry are lower earlier. Even in the year of 2005, none of the apparel companies are inefficient. Nonetheless, the ratio of the inefficient companies in the apparel industry increases in the recent years while the ratio of the inefficient textile companies decreases.

Table 3 shows the total percentages of input excesses and output shortfalls in each year. The average input excess percentages in the input "Net assets" becomes 0.946, 0.984 and 0.106 . Although, it reaches above 0.90 in the textile and apparel industries, the input excesses in terms of "Net assets" are different in each year taking even zero values in some years.

Considering the average percentage values and the percentage values in each year together, the worst year is 2003 and then both of the industries improve their benefits from the resources by decreasing their slacks in net assets.

More input excess is observed in the input "Number of employee" which gets the average values of $3.140,1.9780$ and 2.438 respectively. Regarding the usage of employees, the apparel industry, which is much more labor intensive, shows less success than the textile industry. That means the capacity utilization in terms of that input requires more effort. 
Examining the results of the industry in terms of output shortfalls, the textile and apparel industries individually and two industries in general show poorer performance in maximization of the outputs. The average output shortfall becomes in the output of "Profit before tax", $4.245,16.088,1.040$ for the apparel, textile and two industries in general, respectively. Even, 2006 and 2007 became very painful for the textile industry whereas 2006 is the worst year in terms of efficiencies. The output shortfalls are high for apparel industry in those years but the scores lag far behind the textile industry.

Regarding the two outputs of "Export revenue" and "Gross value added", the apparel industry is lacking of output shortfall in the output of "Export revenue" while the textile industry is lacking basically of the output "Gross value added".

\begin{tabular}{|c|c|c|c|c|c|c|}
\hline$\%$ & Years & $\begin{array}{c}\text { Net } \\
\text { Assets }\end{array}$ & $\begin{array}{l}\text { No of } \\
\text { Employee }\end{array}$ & $\begin{array}{l}\text { Profit } \\
\text { before } \\
\text { tax }\end{array}$ & $\begin{array}{l}\text { Export } \\
\text { revenue }\end{array}$ & $\begin{array}{l}\text { Gross } \\
\text { value } \\
\text { added }\end{array}$ \\
\hline \multirow{6}{*}{ 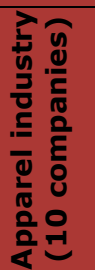 } & 2003 & 4.506 & 4.100 & 7.015 & 8.521 & 3.261 \\
\hline & 2004 & 0.000 & 3.919 & 3.281 & 0.000 & 0.000 \\
\hline & 2005 & 0.000 & 2.047 & 5.694 & 0.000 & 3.190 \\
\hline & 2006 & 0.000 & 3.813 & 5.119 & 0.000 & 1.370 \\
\hline & 2007 & 0.000 & 3.531 & 2.719 & 2.142 & 1.218 \\
\hline & 2008 & 1.169 & 1.430 & 1.640 & 1.036 & 0.000 \\
\hline \multicolumn{2}{|c|}{ Average } & 0.946 & 3.140 & 4.245 & 1.950 & 1.506 \\
\hline \multirow{6}{*}{ 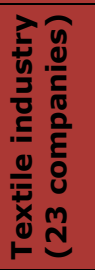 } & 2003 & 1.661 & 1.419 & 17.744 & 3.433 & 9.611 \\
\hline & 2004 & 1.032 & 3.350 & 0.476 & 4.466 & 0.162 \\
\hline & 2005 & 1.693 & 5.602 & 0.983 & 0.000 & 0.482 \\
\hline & 2006 & 0.000 & 0.000 & 30.524 & 0.085 & 1.795 \\
\hline & 2007 & 1.517 & 1.505 & 42.238 & 10.029 & 8.743 \\
\hline & 2008 & 0.000 & 0.000 & 4.562 & 0.088 & 2.133 \\
\hline \multicolumn{2}{|c|}{ Average } & 0.984 & 1.980 & 16.088 & 3.017 & 3.821 \\
\hline \multirow{6}{*}{ 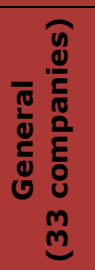 } & 2003 & 0.637 & 4.626 & 2.951 & 8.788 & 3.861 \\
\hline & 2004 & 0.000 & 2.275 & 0.421 & 3.131 & 0.077 \\
\hline & 2005 & 0.000 & 3.530 & 1.114 & 1.783 & 0.545 \\
\hline & 2006 & 0.000 & 2.601 & 0.818 & 3.030 & 0.380 \\
\hline & 2007 & 0.000 & 0.878 & 0.403 & 4.850 & 1.270 \\
\hline & 2008 & 0.000 & 0.720 & 0.533 & 1.453 & 0.019 \\
\hline \multicolumn{2}{|c|}{ Average } & 0.106 & 2.438 & 1.040 & 3.839 & 1.025 \\
\hline
\end{tabular}

Table 3. The Total Percentage of Input Excesses and Output Shortfalls

The apparel industry shows most output shortfall of export revenue in 2003 after when it gets zero values in following three years. But the output shortfall occurs in 2007 and 2008 again. As the apparel industry is more export oriented than the textile industry, the increase in terms of output shortfall can be taken as signal for taking much care. For the textile industry, on the other hand, the output shortfall becomes lower in the recent years except 2007. Such a huge increase in terms of export revenue shortfall draws attention to the fluctuation in export values. The two industries in general mostly lacks because of the output shortfall of export revenue which gets highest value of 3.839 when compared with the output shortfall of "Profit before tax" and "Gross value added" that are 1.040 and 1.025 respectively. That means when all the companies are considered together, the output shortfall of the textile industry in terms 
of export revenue becomes much more apparent. Based on the findings about the input excesses and output shortfalls, it can be concluded that, the capacity utilization in terms of number of employees is important for both of the industries. Nonetheless, it is much more suggested to increase the outputs especially the profit before tax and export revenues.

Briefly, in this study, the efficiencies of textile and apparel companies are analyzed by inputoriented DEA model under variable return to scale assumption. The analysis are first performed for the textile and apparel industries individually, and then for both industries in general. The analysis reveal that the average efficiency scores of the apparel industry is higher than the textile industry and two industries together whereas the standard deviations and the $\mathrm{CV}$ values of apparel industry is much lower than those. In addition, 10 companies from the textile, 3 companies from the apparel and 16 companies from both the textile and apparel industries get a lower average DEA score for the whole period analyzed. Although the apparel industry showed the highest stability with the six companies being efficient in whole period of selected years, the ratio of the inefficient companies in two industries in general increased in the recent years. Regarding the input excesses and output shortfalls, it is not reasonable to state that the net assets and number of employees to be reduced in order to increase the efficiency; on the other hand, it may be recommended that the companies in the apparel industry should overcome the lack of insufficient level of exports, which will also lead to increase the efficiency of the textile and apparel industry as a whole. Finally, the textile industry needs to increase gross value added in order to be more efficient.

\section{Conclusion}

This study provides a framework for DEA application in determination and comparison of efficiency performance in an industry level.

Selecting the groups compared as textile industry, apparel industry and the two industries in general allowed discussing the comparative efficiencies of two industries eliminating the industry specific pitfalls. The DEA characteristic of considering more than one input and output at a time was benefited in order to obtain numerical values for comparison. Multidimensional evaluation of different aspects was established by carefully selection of the input and output parameters considering the previous studies. Inspection of more than one aspect eliminated the possible errors that can be caused from selection of only one input and output. Moreover, the results were enriched with the additional analysis of input excesses and output shortfalls by expanding the study to cover the factors lying beneath the inefficiencies. Within these regards, DEA is a suitable tool to make performance evaluation and to compare the performances of industries enabling the decision makers to better analyze the situation. 


\section{References}

Adler, N., Friedman, L., \& Stern, Z.S. (2002). Review of ranking methods in the data envelopment analysis context. European Journal of Operational Research, 140, 249-265. http://dx.doi.org/10.1016/S0377-2217(02)00068-1

Altin, H. (2010). Financial efficiency test of the ISE industrial companies in the global crisis environment: Data envelopment analysis application. Anadolu University Journal of Social Sciences, 10(2), 15-30. http://dx.doi.org/10.1023/A:1022804419183

Alvarez, R., \& Crespi, G. (2003). Determinants of technical efficiency in small firms. Small Business Economics, 20, 233-244.

Arig, T.T. (2011). Data envelopment analysis as an efficiency calculation method and application including evaluation about the relative financial efficiencies of ISE industrial companies. Istanbul: Yildiz Technical University Institute of Social Sciences.

Ayvaci, O.A. (2011). Is Turkey Profitable. Retrieved from capital: http://www.capital.com.tr/isturkey-profitable-haberler/23259.aspx?1.Page

Banker, R.D., Charnes, A., \& Cooper, W.W. (1984). Some models for estimating technical and scale inefficiencies in data envelopment analysis. Management Science, 30(9), 1078-1092. http://dx.doi.org/10.1287/mnsc.30.9.1078

Bayrak, A., Ozcan, A.I., Anil, N.K., \& Emre, F. (2003-2004). Istanbul ilinden secilmis tekstil sektorune ait firmaların veri zarflama analizi ile etkinliklerinin olculmesi. Review of Social Economic and Business Studies, 3/4, 161-177.

BTSO, B.T. (n.d.). Tekstil ve konfeksiyon sektoru yeniden yapilanmak zorunda. Retrieved 08 22, 2012, from bursaekonomi:

http://www.bursaekonomi.com.tr/default.asp?page=newsopen.asp\&opennews=152\&qmshow $=211$

Chandra, P., Cooper, W.W., Shanling, L., \& Rahman, A. (1998). Using DEA to evaluate 29 Canadian textile companies-Considering returns to scale. International Journal of Production Economics, 54(2), 129-141. http://dx.doi.org/10.1016/S0925-5273(97)00135-7

Charnes, A., Cooper, W. W., \& Rhodes, E. (1978). Measuring the efficiency of decision making units. European Journal of Operational Research, 2, 429-444. http://dx.doi.org/10.1016/0377$\underline{2217(78) 90138-8}$

Cook, W.D., \& Zhu, J. (2008). Data envelopment analysis: Modelling operational processes and measuring productivity.

Cubbin, J., \& Tzanidakis, G. (1998). Regression versus data envelopment analysis for efficiency measurement: An application to the England and Wales regulated water industry. Utilities Policy, 7, 75-85. http://dx.doi.org/10.1016/S0957-1787(98)00007-1

Duzakin, E., \& Duzakin, H. (2007). Measuring the performance of manufacturing firms with super slacks based model of data envelopment analysis: An application of 500 major industrial enterprises in Turkey. European Journal of Operational Research, 182, 1412-1432. http://dx.doi.org/10.1016/j.ejor.2006.09.036 
Emrouznejad, A., Parker, B.P., \& Tavares, G. (2008). Evaluation of research in efficiency and productivity: A survey and analysis of the first 30 years of scholarly literature in DEA. SocioEconomic Planning Studies, 42, 151-157. http://dx.doi.org/10.1016/j.seps.2007.07.002

Goncharuk, A. (2007). Impact of political changes on industrial efficiency: a case of Ukrain. Journal of Economic Studies, 34(4), 324-340. http://dx.doi.org/10.1108/01443580710817443

Gonzales, M. M., \& Trujillo, L. (2008). Efficiency measurement in the port industry: A survey of the empirical evidence. Discussion paper series(7). City University Deparment of Economics.

Gozu, C. (2003). Veri zarflama analizi ile etkinlik olcumu ve tekstil isletmelerine yonelik bir uygulama. Ankara: Ankara University Institute of Social Sciences.

Jajri, I., \& Ismail, R. (2006). Technical efficiency, technological change and total factor productivity growth in Malaysian manufacturing sector. http://mpra.ub.unimuenchen.de/1956/1/MPRA_paper_1956.pdf adresinden alınmıştır

Kayali, C.A. (2009). Evaluation Financial Profitability Efficiencies of Textile Companies in 2007. Tekstil ve Konfeksiyon, 1, 3-8.

Kayalidere, K., \& Kargin, S. (2004). Cimento ve tekstil sektorlerinde etkinlik calismasi ve veri zarflama analizi. Dokuz Eylul University Journal of Graduate School of Social Sciences, 6(1), 196-219.

Laughlin, J., \& Kean, R.C. (2002). Benchmarking for strategic planning based on faculty productivity. Clothing and Textiles Research Journal, 20, 147-154. http://dx.doi.org/10.1177/0887302X0202000303

Lin, S., Kincade, D.H., \& Warfield, C. (1994). Productivity and production in the apparel industry. International Journal of Clothing Science and Technology, 6(1), 20-27. http://dx.doi.org/10.1108/09556229410054477

Loker, S. (2002). People and technology management in flexible manufacturing :An apparel industry case study. Clothing and Textiles Research Journal, 20-26.

Ray, S.C. (2004). Data envelopment analysis: Theory and techniques for economics and operations research. Cambridge: Cambridge University Press. http://dx.doi.org/10.1017/CBO9780511606731

Sherman, H.D., \& Zhu, J. (2006). Service productivity management : Improving service performance using data envelopment analysis . Boston: Springer Science.

Taymaz, E., \& Saatci, G. (1997). Technical change and efficiency in Turkish manufacturing industries. Journal of Productivity Analysis, 8, 461-475. http://dx.doi.org/10.1023/A:1007796311574

Tektufekci, E. (2010). Evaluation of financial efficiency by data envelopment analysis in Istanbul Stock Exchange listed publicly traded technology companies. Organizasyon ve Yonetim Bilimleri Dergisi, 2(2), 69-77.

Tongzon, J. (2001). Efficiency measurement of selected Australian and other international ports using data envelopment analysis. Transportation Research Part A, 35, 107-122. http://dx.doi.org/10.1016/S0965-8564(99)00049-X

Worthington, A. C. (2001). An empirical survey of frontier efficiency measurement techniques in education. Education Economics, 9(3), 246-268. http://dx.doi.org/10.1080/09645290110086126 
Yalama, A., \& Sayim, M. (2008). Veri zarflama analizi yontemi ile imalat sektorunun performans degerlendirilmesi. Dokuz Eylul University Faculty of Economic and Administrative Sciences Journal, 23(1), 89-107.

Zhang, Q., \& Hathcote, J.M. (2008). Factors influencing apparel imports from China. Clothing and Textiles Research Journal, 26-23.

Zhu, J. (2003). Quantitative models for performance evaluation and benchmarking. Springer Business Media.

Journal of Industrial Engineering and Management, 2012 (www.jiem.org)

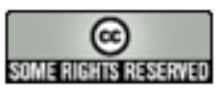

El artículo está con Reconocimiento-NoComercial 3.0 de Creative Commons. Puede copiarlo, distribuirlo y comunicarlo públicamente siempre que cite a su autor y a Intangible Capital. No lo utilice para fines comerciales. La licencia completa se puede consultar en http://creativecommons.org/licenses/by-nc/3.0/es/ 